\title{
EXPLORING THE POTENTIAL FOR RELIGIOUS SCHOLARSHIP IN 'POST' POST-CONFESSIONAL RELIGION EDUCATION IN STATE-FUNDED SOUTH AFRICAN SCHOOLS
}

\author{
Janet Orchard \\ University of Bristol
}

Nuraan Davids

Department of Education Policy Studies

Stellenbosch University

\begin{abstract}
'Christian National Education' (CNE) was promoted in South Africa between 1948 and 1990 by the then apartheid government to enhance and preserve white supremacy through the public schools' system. One significant educational reform following the introduction of democratic governance in South Africa was the replacement of 'Religious Education' with 'Religion Education', intended to promote mutual recognition between future citizens, regardless of religion, ethnicity or culture. Yet, however preferable to what preceded it, this policy introduced inherent and unique limitations and difficulties we, two philosophers of education, one South African, the other English, explore while keeping in mind the place of religion in the curriculum. We see clear lessons to be learned from the South African experience of RE that are relevant to both contexts, adopting what we describe as a 'post'- post-confessional stance to advocate a richer notion of religious illiteracy than that which is commonly assumed by policy makers, educational professionals and other educational stakeholders. We conclude by exploring the potential of academic learning in RE that is both educative and consciously positioned, using the specific example of sacred text scholarship to illustrate 'post' post-confessional RE's practical application.
\end{abstract}

Keywords: Post-confessional Religious Education; South Africa; England; Crosscultural attraction; Hermeneutics

\section{Introduction: The post-apartheid National Policy on Religion and Education}

We have argued previously (Davids and Orchard, accepted for publication) that the historical and political context behind the current negotiated stance on Religion Education in South African schools must be appreciated to make sense of what it requires. In particular, the relationship between religion and education being assumed in the National Policy on Religion and Education (DoE 2003) needs unpacking, as well as the inherent challenges posed by the wider policy context. South Africa has long been regarded a religiously active society (see Nogueira-Godsey 2016); yet, prior to its democracy, this vibrancy was cushioned exclusively in a Christo-centric discourse that divided racial groups and preserved the privileges of whiteness. After 1948 under 
apartheid, the 'Christian National Education' (CNE) curriculum was developed as guiding philosophy for state-funded schools. With all schooling regarded as inherently 'Christian', apartheid theology was used as a benchmark for how society as a whole could be organised (Corrado 2013). Schools were treated like racialized 'congregations', requiring the segregation of learners across four racial categories in the following hierarchical order: white; Indian, coloured and black. All school-going children, regardless of background, were expected to participate in the schools' 'Christian' ethos: prayers were to be recited at key moments during the school day, before sporting events and at school assemblies, which also included the singing of a hymn. No other religion or worldview was acknowledged, let alone included. Religious Instruction was positioned within $\mathrm{CNE}$ as a curriculum subject purposed for evangelism, nurturing specific values and principles.

In the post-apartheid period, the National Policy on Religion and Education (DoE 2003 ) introduced to replace CNE is premised very differently. First, South Africa is recognised as home to a wide variety of religions and major world faiths and a deep and enduring indigenous religious heritage, including $60 \%$ of the population who declare allegiance to Christianity. The internal diversity of understandings and practices within each tradition is recognised, as are those South Africans who draw their understanding of the world, ethical principles, and human values from sources independent of religion. In the most "profound matters of life orientation", the current policy asserts, "diversity is a fact of our national life" (DoE 2003:6). In the face of that religious plurality, the policy identifies 'life orientation' as a shared human endeavour upon which a valuable state-endorsed educational entitlement might be developed.

Pursuing that common ground, strict separation of religion and the state in education underpins the policy and is assumed to be a beneficial step, while recognising 'scope for interaction between the two' and the need for a 'relationship between religion and education' (DoE 2003:3) that will best serve the interests of a democratic society. Statefunded schools are afforded educational responsibility for teaching and learning about religion and religions in ways that are different from the 'instruction and religious nurture provided by the home, family, and religious community’ (DoE 2003:3). Thus, a binary relationship is established between the kind of religious understandings which develop within the public sphere of schooling, on one hand, and those which develop in private religious settings on the other. This move may be understandable given South Africa's history, but has proved problematic (Davids and Orchard, forthcoming) because a false dichotomy ensues, privileging a perceived 'neutral' educational perspective over a value-laden religious one. Some schools have adopted the National Policy (DoE 2003), others have replaced it with a secular enunciation of values and others have rejected it. Furthermore, a number of parents, fearing the prospect of their children being exposed to 'God-less' schools and/or 'other' religions have opted out of state-funded education altogether in favour of 'faith-based' or home-based schooling. (Driesen \& Tayob 2014).

As these responses indicate, that so-called 'educational' view itself is value-laden. Matters of the state are better off, it is assumed, when religion and political control are strictly separated. Critique of the claim that a secular view adopts a neutral stance with regard to religion and education is well-established (e.g. Teece 2008; Barnes and Wright 2006) although it remains widely supported, particularly although not exclusively in republics around the world. It should come as no surprise that in South Africa, as 
Exploring the Potential for Religious Scholarship in 'Post' Post-Confessional Religion Education 3 elsewhere, those citizens who do not share that assumption, believing that political and religious decision-making are inescapably inter-connected, will be critical of policy making rooted in this position, even where in other respects they might be supportive of a strong break post-apartheid. Christian groups in particular, given the country's historical Christo-centric leaning, have interpreted the policy negatively as a move by secularists to remove religion from schools, and School Governing Bodies, with highprofile critics including school principals.

Hence, despite the introduction of a series of reform measures geared at making South African schools more inclusive and open to diversity, a number of schools persist in propagating Christianity - either on the basis of historical identities and contexts or on claims that most of its learners are Christian (see Driesen \& Tayob 2014; NogueiraGodsey 2016). And in numerous reported incidents, learners have been subjected to discriminatory practices when they attempt to assert their respective religious identities. In response to one such case, a non-governmental organisation known as, the 'Organisation for Religious Education and Democracy' (OGOD), which is focused on eradicating religious indoctrination at public schools, succeeded in its application to the South African High Court to declare the religious policies at six public schools unconstitutional. The schools were accused of promoting Christianity along lines reminiscent of $\mathrm{CNE}$, by forcing learners to participate in Christian religious observances at school assembly, including reading sacred texts. Moreover, they opened the school day with a prayer, while also saying a prayer before exams or before and after sports matches, singing hymns or other religious songs, and promoting Christian symbolism on the school badge or coat of arms (Staff reporter 2017).

In opposing the application, the schools, represented by the Federation of Governing Bodies of South African Schools (Fedsas), admitted to having a Christian ethos and promoting Christian values on the basis that the majority of their learners belong to the Christian faith. Participation in religious observances while at school was voluntary, they continued, and those not wanting to participate were accommodated otherwise, for example in the provision of supervised classes, or by being allowed to come to school at a later time (Staff reporter 2017). Moreover, the schools maintained that as education by definition 'cannot prescribe multi-faith religious observances', no-one, whether a learner or a teacher, could be required to lead or participate in 'religious observance that is not of their own chosen faith or belief', for to require a learner or teacher to do so 'offends the core of the right to freedom of religion'.

Such counter arguments illustrate profound misinterpretations of current policy. Clearly, the schools involved, could not, or refused to, comprehend that mainstreaming Christian religious observance in the public space of a school could potentially cause offence to others. Nogueira-Godsey (2016:236), for example, found that despite teachers' apparent insights into a multi-religious approach to teaching RE, they could not recognise teaching and encouraging Christian prayer as a form of religious confessionalism. After a three-year battle between OGOD and Fedsas, the court issued a declaratory order confirming that a public school cannot promote that it adheres predominantly to only one religion to the exclusion of others or hold itself out as promoting the interests of one religion over others. According to Ntho-Ntho \& Nieuwenhuis (2016:241), key areas of conflict hinge on the following: exemption of children from certain classes with 'objectionable content', the extent to which parents 
may influence content selection in classes, whether prayer is permitted in schools or at school activities, and the extent to which religious student groups may exist in schools.

Central to parents' concerns is the perception that although the state purports to separate religion from the state - unlike the $\mathrm{CNE}$ - its objective to propagate religious diversity may be interpreted as an interference in religion rather than a neutral separation. The challenge for policy makers resides in how to restructure the relationship between religion and education, so that a shift away from an exclusivist Christian and confessional conception of RE towards an approach that is inclusive of multiple traditions does not alienate religious adherents. While this issue is not exclusive to South Africa, it is particularly complex here, given its post-apartheid CNE context.

We turn from this review of the interpretation of the relationship between religion and education in schooling promoted by the current dominant discourse to a consideration of 'Religion Education' (RE), the specific curriculum which the National Policy proposes, based on the assumptions just highlighted. Schools are assigned responsibility for teaching about religion and religions on this account, in ways that are intended to reflect a profound appreciation of the spiritual and non-material while facilitating understanding of, and regard for others, and engaging with those differences which constitute its diverse society. As before, the drawing of a rigid distinction between $\mathrm{RE}$ and Religious Instruction (RI) as a necessary step in breaking from CNE has contributed to the alienation of significant numbers of the country's citizens, with a significant increase in numbers of schools of a religious character reported, creating new clusters of segregation. Values with which Religion Education in South Africa from 2003 is connected, include 'new initiatives in cultural rebirth' (the African Renaissance), 'moral regeneration, and the promotion of values in our schools' (DoE 2003: 5).

All valuable in themselves, these assumptions are implied as being 'generic' to religion(s) without due regard to the complexity within, and between religions, and wider worldviews with which they might be interpreted, despite the policy itself identifying internal differences as a lived reality in these groups. Furthermore, it is argued that religion education should promote these values so that they 'flow directly from the constitutional values of citizenship, human rights, equality, freedom from discrimination, and freedom of conscience, religion, thought, belief, and opinion' (DoE 2003: 5). This is not to suggest inherent problems with these values per se. Yet, the net effect of this emphasis has been for humanistic values to be promoted as intrinsically worthwhile as the potential value within specifically religious iterations of these values (Ferreira \& Schulze 2014) is downplayed.

$\mathrm{RE}$ in its current form is a curricular programme "with clear and age-appropriate educational aims and objectives for teaching and learning about religion, religions, and religious diversity in South Africa and the world' (DoE 2003: 9). It should be noted that the contention that knowing about religion necessarily promotes religious diversity is far from certain (Orchard 2015), and there is a clear need to investigate this matter further, in South Africa and elsewhere. Current support for this assumption tends to rely on selfreports and anecdotal information. Given numerous incidents of discriminatory actions and speech in schools (Davids and Orchard, forthcoming) there must be considerable doubt that RE in schools in South Africa is proving effective in this regard. At the time of writing, and coinciding with a global awareness of 'Black Lives Matter', there have been hundreds of highly disturbing accounts of racism and Islamophobia from current 
Exploring the Potential for Religious Scholarship in 'Post' Post-Confessional Religion Education 5 and past learners - trending under the hashtag, 'you silence, we amplify'. Seemingly, South Africa's (desegregated) schools serve as intense spaces of racial, religious, cultural, ethnic, and linguistic tensions - not only between learners but also between teachers and learners.

However, even if a connection between teaching about religions and more positive inter-religious group relations were proven, South Africa's national curriculum, the Curriculum and Assessment Policy Statement (CAPS) (DBE 2011), offers relatively few opportunities to teach about religion explicitly, given that RE forms one part of the Life Orientation curriculum. Some sense of the challenge facing teachers may be gained from a cursory glance at the myriad topics teachers are required to cover, for example, at Intermediate phase level (grades $4-6$ ). $\mathrm{RE}$ is addressed within the themes of knowledge of major religions in South Africa, festivals and customs across a variety of religions represented in the country, and cultural rites of passage. Given limited curriculum time and a heavy load of additional curriculum content needing to be covered in Life Orientation, the attention paid to religious knowledge may be little more than tokenism. The conflation of RE with democratic citizenship education is evident at Senior phase level (grades $7-9$ ), where RE is addressed within the topic of 'Constitutional rights and responsibilities' (DBE 2011: 8); and at the level of Further Education and Training (FET, grades $10-12$ ), where it falls under the topic of 'Democracy and human rights'. Here, the curriculum requires the teaching of diversity, discrimination, human rights and violations; ethical traditions and/or religious laws and indigenous belief systems of major religions; contributions of South Africa's diverse religions and belief systems to a harmonious society; and ideologies, beliefs and worldviews on construction of recreation and physical activity across cultures and genders (DBE 2011: 10). Such content-heavy and prescriptive requirements allow insufficient time and space to do either subject justice.

The knowledge-rich curriculum which the National Policy on Religion and Education (DoE 2003) proposes, covers as much subject content as possible, so that learners might increase their knowledge about different faiths. Knowledge-rich teaching requires knowledgeable teachers, yet not all Life Orientation teachers have that knowledge. Ironically, while the National Policy on Religion and Education (DoE 2003) seeks to promote 'religious literacy', teacher quality is relatively poor, so that too often teachers of RE themselves, as well as schools, are religiously 'illiterate'. A 'legitimate concern about the widespread 'religion illiteracy' found among teachers' (Do, 2003: 16) is acknowledged, despite the provision of 'Teaching materials for Religion' (DoE 2003: 16) in both cases. Research conducted by Nogueira-Godsey (2016: 231) confirms that, in the South African context, teachers' subject knowledge is a problem, particularly in relation to non-Christian religious traditions; while other teachers interviewed, pointed to a lack of skills to teach the subject due to a superficial understanding of the subject's purpose (Nogueira-Godsey 2016). It should be noted that this problem is not unique to South Africa, but is found also in England, as a series of reports by the subject community (e.g. APPG 2012; REC 2013; REC 2018) highlights.

Even were those teachers more knowledgeable about religion and other worldviews, be they indigenous traditions or secular perspectives on the world, where teachers lack the confidence and competence to engage learners critically with those systems of belief, as promoted by academic traditions, the notion of literacy being deployed is somewhat 
impoverished. Roux (2010) goes further, arguing that in RE the knower should be encouraged to develop 'self-identification (the self) and to communicate with understanding with/or about world opinions (the other)' (Roux 2010). This relational engagement (Roux 2010: 993) 'is not a natural process', being related to, but going beyond qualities of empathy or intuitive understanding; it needs to be taught. However, current initial teacher education programmes suggest that not enough emphasis or attention is granted to teacher identity and the inevitable intersectional tension between personal beliefs and professional requirements (Davids 2019; Orchard and Davids 2019). Again, South Africa is not alone in this regard (Orchard, Heilbronn and Winstanley 2020; 2016), although we do not wish to downplay the particular challenges this country faces, given its geographical and political positioning and post-conflict, post-apartheid legacies.

In pedagogical terms, both Andrew Wright (1996) and Roux (2010) couch 'religious literacy' in the context of a discourse or conversation, something we relate to strongly, given our own experience of learning through the experience of dialogical encounter. Yet, the understanding that self-awareness and reflexivity are critical to religious literacy is in tension with the insistence that RE be entirely different from notions of religious instruction as provided and influenced by the home, family and religious communities. In this regard, Kathryn Wright argues for the open 'embrace' of otherness and 'being hospitable' in RE teaching, with the host giving of themselves in the encounter (Wright 2017: 229) more than simply providing hospitality.

The challenge, as Roux (2010: 994) expresses it, is as follows:

'What will happen when the teacher is not within his/her own inner space and does not buy into a process of reconstructing his/her perceptions and world-view or religious understanding of the other?' (Roux 2010: 995).

There is a tension in both contexts between teachers as agents of interreligious teaching and learning and as representatives of their own life stances in an educational and multireligious environment.

The National Policy on Religion and Education (DoE 2003) assumes that 'religious literacy' as 'knowing that' about different 'worldviews, cultural practices, and ethical resources of humanity' may be combined through the positioning of this curriculum within a form of civic education, in which 'the capacities for mutual recognition, respect for diversity, reduced prejudice, and increased civil toleration that are necessary for citizens to live together in a democratic society' (DoE, 2003: 10) may be developed. We have already highlighted the lack of evidence in either context with which we are familiar that RE positioned along these lines has contributed significantly or systemically to changing social attitudes (Orchard 2015), and there is some concern that a little knowledge may be a dangerous thing. Where ill-informed and non-specialist teachers of $\mathrm{RE}$, faced with constraints of curriculum time, are given long and overly-prescriptive lists of subject content to cover, the likelihood of these ambitious aims being fulfilled is limited. Even accepting that there may be localised examples of good practice based on inspired teaching, education for mutual understanding is unlikely to be promoted by the RE curriculum alone, but attributable to a more complex range of factors. 
We maintain that the binary opposition of homes, families, and religious communities as sites of confessional religious education and schools as sites of a post-confessional, implicitly educationally superior form of religious education is unrealistic as well as unhelpful. Yet a notion of 'religious literacy' along the lines just sketched, could potentially help to address these fears, following the lead of Roux (2010) and others in extending this term beyond a concern with knowledge and understanding of religion alone to include more ontological notions of being and becoming which allow for a more personal dimension to these programmes of study. This is not to dismiss at all the value of learning about religions and beliefs at school; rather, to re-imagine the language of religious literacy so that it captures adequately and appropriately notions of RE better suited to state level policy making, in South Africa and elsewhere. This re-imagining needs to describe a subject which can connect academic learning with forms of personal and social education which socialise rather than indoctrinate children and young people; and which include, but are not limited to notions of formal religion; and which encourage acceptance of the 'other'. Furthermore, arguments for personal and social education of this kind must continue to enjoy support alongside outcomes-based approaches to education focussed on results of high stakes testing.

\section{Cross-national attraction in state-funded Religion Education policy: A dialogue}

Our developing sense of a shared understanding of priorities for teaching religion in state-funded schools in our respective contexts has arisen out of an ongoing dialogue between us, as philosophers of education who are concerned with the place of ethical deliberation in teacher education. Schoolteachers teach children and young people as much as subjects, i.e. their work rests fundamentally on pedagogical relationships and these are inter-connected. Recognising the significance of the human dimension in teaching, our 'deliberation on deliberation' has been conducted through a series of extended private conversations and academic deliberations and collaborations, either through writing or conference presentations.

In developing academic theory about ethics and teaching, we cannot bracket out our personal selves; religious identity and commitment matter to us both, although our respective commitments are different. 'Religious literacy' for us draws on our personal commitments as well as our commitments to scholarship in Theology and Religious Studies along lines we have already indicated. We have come to share an understanding of 'religious literacy' that resists the binary implicit to the secular viewpoint promoted through the National Policy on Religion and Education (DoE 2003). We argue that to retain that binary compromises the promotion of religious literacy through RE in statefunded schools in both our countries, recognising that those contexts are very different. We have chosen for that reason to frame our reflections by responding specifically to one policy context, i.e. the SA policy situation. A similar exercise might have been conducted by us focussed on one of the recent policy recommendations for RE in England (e.g. REC 2013; REC 2018); however, while we refer to those documents and to relevant theoretical insights that have been developed by RE scholars in England because their work dominates discussion of these issues, here our gaze is fixed on the SA context.

'Policy borrowing', a term firmly established in the literature of comparative studies in education, is rooted in the false assumption that policy can simply be transplanted 
from one national context to another (Phillips and Ochs 2004: 774). Our approach might better be described as 'cross-national attraction' (Phillips 1989, 1993; Ochs \& Phillips 2002); as conversation between us has developed and deepened, we have identified certain common concerns in our respective experiences, albeit ones that may be more acute in post-apartheid South Africa. Given this mutual and reciprocal process of shared reflection on policy and practice through the lens of religious, ethical, and philosophical deliberation, we have come to identify aspects of practice in our respective contexts whereby each may learn from the other. From a South African perspective, there are curriculum development projects which draw on strong and diverse traditions of theorising about RE in the subject community and which offer promising possibilities for future development at all levels, practice, policy and research. One potential attraction of the South African example for curriculum development from an English perspective is the way in which positive connections are drawn between the religious and political under an umbrella of Life Orientation, albeit with shortcomings. Once stronger connections are drawn between the RE curriculum for schools in South Africa and Theology and Religious Studies in the academy, a decolonised RE curriculum for England would engage far more extensively with South African scholarship. This sense of the potential for co-construction of new understandings of RE as a mutual and reciprocal endeavour represents a shift away from the dynamics of educational reform and the political context informing the writing of the National Policy on RE (DoE 2002) in the early part of this century. Were attractive features of policy and practice of RE in England to be identified by South African educators, these would be reflective of the very best that is said and thought about the subject; teacher quality, non-specialist teaching, the aim of performance in tests at the expense of personal growth, and secularism are also issues for RE teaching in England.

Reflection on potentially promising practice in education found in 'other' places should be deliberate and purposive; Phillips and Ochs (2004) advise avoiding the perils of swift and impulsive appropriation of superficially attractive ideas which might turn out to be fads. From this careful process of considered and careful thought, an impulse and the potential for change (Phillips \& Ochs 2004) may be identified which need then to be translated into argumentation. Important considerations include being realistic and practical about the grounds on which reform might be introduced. Elements that would be key to the success of the reforms proposed, should not be independent of the particular location in which they were originally developed and capable of being introduced successfully elsewhere. We see ourselves at this stage at present in our reflections, needing to tease out further how context specific examples for South African RE might grow from contemporary curriculum models for RE in England.

\section{'Post' Post-confessional Religion Education in South Africa: What should be done?}

Clearly, despite its shortcomings, the National Policy on Religion and Education (DoE 2003) offers a more appropriate alternative to Religious Instruction as propagated in an apartheid-based curriculum. However, two decades is a long time in policy terms and further revision is urgently needed, given advances in the field since then and in light of those unintended practical consequences of the policy which this chapter has served to highlight. In one sense, the stated aims of RE as stated within the Life Orientation 
Exploring the Potential for Religious Scholarship in 'Post' Post-Confessional Religion Education 9 curriculum enjoy a clarity that could be the envy of other jurisdictions. However, and this may serve as a warning to those seeking 'clearer' aims for RE in other parts of the world, the clarity has not enabled either consensus building or 'buy in' by key stakeholders, notable more conservative religious adherents, and this has served to undermine the notion of inclusive RE for South Africa as certain members of the 'rainbow nation' opt out of this provision entirely. More importantly, it has seemingly done little to advance notions of mutual trust, regard, and tolerance - as encountered through increasing rates of religious, ethnic, and cultural tensions and discriminatory practices at schools.

A knowledge-driven curriculum fails to allow for, or enable, reflection on that knowledge, thus further undermining the RE curriculum. Given the secular orientation of the National Policy on Religion and Education (DoE 2003), there is an unwillingness to enter into the act of learning from religion as a personal encounter; doubtless, the scars of the CNE and its confessional and systemic racist outlook run deep. However, to conceive RE narrowly as being concerned with knowledge transfer and observation, particularly given the vibrant religiously plural South African context, does disservice to the religious majority. It also undermines the possibility of education as a reflective and personally engaging endeavour; on academic terms, to exclude from the outset the possibility that academic practice might be both personally engaging as well as knowledge rich is to disaggregate the school curriculum from those disciplines and fields of study as they are practiced in higher education, whether concerned with religion as a phenomenon or the divine in the case of Theology.

Similar to the practice in schools, initial teacher education programmes approach RE as a sub-set of knowledge within LO and, seemingly, with an equally surface approach to ensuring content knowledge rather than deliberative and reflective engagement. Were specialist teachers of RE, academically well-equipped through degrees in Theology and Religious Studies or an in-service equivalent, to 'deliver' this subject in schools, in principle we envisage practitioners who would be skilful in initiating and facilitating learning of this richer kind just described. Learners might be introduced to a critical form of RE in which they were encouraged to learn about and from religion, developing their knowledge and understanding of religious and philosophical perspectives not only on human life but the nature and purpose of existence. More time and greater priority would need to be afforded to teaching RE in South African schools were this to be likely to foster deeper understanding, and potentially greater respect, for other faiths/worldviews. Currently, teachers might neither possess the subject knowledge nor demonstrate professional willingness to engage in critical reflection, participation, and deliberation on religion of the kind that has just been outlined, commonly practised by the academic TRS community. The need for 'training, commitment, and enthusiasm of professional teachers' - referred to as 'religion literacy' (DoE 2003: 14) has long been recognised by policy-makers in South Africa. It is understood in principle that teachers of RE should not only have content knowledge of diverse religions but be prepared and sufficiently culturally and religiously sensitive to teach about these religions. However, being aware of the life-worlds and experiences of students, and what they encounter, so that discriminatory ideas and practices might be identified and remedied, is a 'big ask' of the generic teacher of Life Orientation. 
When considering what this re-imagined version of Religion Education in South Africa might be like, we are reminded of one context in which our cross-national discussions have taken place, namely as part of a process of engagement with theologians and Religious Studies scholars attending an inter-religious symposium, organised by the Centre for the Interpretation of Authoritative Scriptures in Ancient and Contemporary contexts (CIAS), at the University of Stellenbosch in September 2019. This has reminded us of the capacity for university-based scholars of religion and theology, from varied academic backgrounds, personal perspectives, and worldviews, to engage academic expertise in the pursuit of education for mutual understanding; why can't an equivalent experience be offered as an educational entitlement to South Africa's school children? This symposium has inspired us to consider one specific example of the possible post post-confessional approach to RE sacred text scholarship; however, this is not to suggest that RE be reduced to sacred text scholarship alone. Other forms of academic scholarship in the Theology and Religious Studies arena are also potentially relevant and appropriate, but this offers one hopeful place to start.

Religious texts are phenomena with which many people engage, in ways that are socially, personally, and politically relevant. For example, take the way in which secular commentators on climate change invoke biblical apocalyptic to support their political arguments:

"A large body of evidence is beginning to accumulate showing how climate breakdown is likely to affect our food supply. Already farming in some parts of the world is being hammered by drought, floods, fire and locusts (whose resurgence in the past few weeks appears to be the result of anomalous tropical cyclones). When we call such hazards "biblical", we mean that they are the kind of things that happened long ago, to people whose lives we can scarcely imagine. Now, with increasing frequency, they are happening to us." George Monbiot, The Guardian, $25^{\text {th }}$ March, 2020

'Apocalyptic', as it might be more simply defined in the context of a RE classroom, is the term used to describe prophetic writing developed originally among the Jewish communities displaced from Jerusalem and still evident today across the Hebrew Bible and New Testament. Apocalyptic literature relates to or predicts the end of the world, anticipating widespread destruction, even the collapse of civilization. Significant books in the environmentalist canon make use of apocalyptic-style rhetoric, including Rachel Carson's Silent Spring (1962), Paul (and Anne) Ehrlich's The Population Bomb (1968), as well as Gore's Earth in the Balance (1992). The promotion of learners' religious literacy through exploring influential worldviews like these might be argued as relevant and necessary in the contemporary RE classroom, with a hermeneutical approach being argued for by Aldridge (2018), a philosophical line by Bowie and Coles (2018), and a sacred-text-scholarship line by Panjwani and Revell (2018) and Docherty (2018).

Exploring religious and ideological responses to climate change and environmental crises would address the aims of RE as stated in the National Policy on Religion and Education (DoE 2003) but prove both an educative and academic affair. As worldwide school strikes and the global attention afforded Greta Thunberg during 2020 testify, such topics resonate with the interests and concerns of young people. One way to engage with 
Exploring the Potential for Religious Scholarship in 'Post' Post-Confessional Religion Education 11

Thunberg's ideas distinctively in ways that engage religious forms of knowledge and understanding going beyond Personal, Social and Health Education (PSHE) or Citizenship would be to analyse the language she uses, against the characteristic structure of apocalyptic writing, given that climate catastrophe narratives may mirror religious ones. This may happen along comic or tragic lines; another useful resource with older learners could be the comic, but macabre story When the Wind Blows, by Raymond Briggs (1986), in which a middle aged couple, Jim and Hilda Bloggs, roll up their shirtsleeves as the countdown begins, following genuine guidelines distributed to households around Britain in the 1970s. They paint their windows white; build a fortress of doors and pillows; take the washing in; and put away two packets of ginger nuts, one tin of pineapple chunks, and a good supply of tea in preparation for the bomb that is about to drop on them. In Thunberg's speeches, the characteristics of a tragic account of impending environmental doom are followed, and these include a clearly divided sense of good and evil in the narrative as well as preordained consequences if the wrong course of action is taken, another rhetorical device found commonly in apocalyptic narratives. Again, these kinds of interpretations and expressions are not unique to an English context. Recently, South Africa's drought, followed by the Covid-19 pandemic, has seen religious leaders berating their congregants for bringing the wrath of God onto themselves. Relief from the drought and the pandemic, therefore, can only be achieved through living 'cleaner' and 'God-fearing' lives.

Moreover, the deployment of apocalyptic narratives in popular culture only works when both writer and reader notice the cultural reference. They also continue to exercise authority over people, whether or not they are religious, as the following example illustrates. A former learner managed to persuade her classmates that the end of the world was likely to happen the following day. A lunch break was spent, there being no time in the lesson to undertake this task, with Clare (not her real name) and her 'friends' (who were Muslim), pouring over the relevant Biblical passages she was citing out of context. In this case, the teacher, while no Biblical expert, was able to draw on her sketchy knowledge of eschatology, that part of theology concerned with the end times and humanity's ultimate destiny, to address both the pastoral and academic nature of the discussion. 'Clare' was a troubled individual, half believing the story, given her nihilist perspective on life, while also taking a certain kind of pleasure in terrifying her impressionable peers who half-believed her.

Here, the role of the RE teacher might be understood as one of promoting critical reflection on the Bible in a non-confrontation way which would challenge 'Clare's' unthinking Biblical literalism. At no point did she impose one 'right' reading of the texts being reviewed, and some readings could be shown to be deficient or implausible. As Jerome Bruner (1996) observed, there may be no learning more 'enspiriting' than that of engaging critically with authoritative ideas that have stood the test of time. Being 'critical' here concerns evaluating and developing judgements in relation to other people's beliefs and ideas in ways that are rigorous and well informed according to the standards of the academic approach being deployed. Too often in popular opinion, being critical may be equated with writing other people's views off or immediately rubbishing them, rather than recognising that there may be different legitimate and some illegitimate readings of political as well as religious texts. Thinking through what might constitute age appropriate tasks and activities for school-aged learners, there are fascinating 
discussions to be had, reflecting on why the text was written in the first place; what this reveals about the writer; and how readers react, including ourselves in that reflection.

\section{Concluding thoughts}

In seeking to balance the 'familiar' with the 'unknown', the intention of the National Policy on Religion and Education (DoE 2003) is to provide learners with an opportunity to develop a deeper sense of self-realisation and a broader civil tolerance of others. The interpretation and implementation of the policy, however, has played out quite differently. In separating religion from education, the unintended effect has been a binary construction and tension between schools as secular sites and homes as religious spaces. The ensuing perceived dichotomy stands in stark contradiction to reconciliatory tone propagated by the policy. With this tension in mind, an understanding of 'religion literacy' has been proposed to address the inherent problems in RE in South Africa created by the current interpretation.

Given the long-standing connections South Africa enjoys with other jurisdictions facing related, albeit contextually different difficulties with regard to RE, mutual and reciprocal partnerships might fruitfully be formed between suitably qualified researchers, policy makers, and practitioners. Going beyond 'policy borrowing' to the kind of alliance we have sketched, we might share insights and work creatively and imaginatively together to develop forward looking responses to these deep-seated and hard-to-resolve problems. An initiative of this kind is anticipated by the authors, who see the agenda of this current chapter as a starting point for collaborations of this nature. Key to this initiative are the 'significant actors' - people (or institutions) with the power to support or resist development and change.

To date, post-apartheid policy, while critical, has at times followed a hasty route, which has often excluded essential voices. Notably, teachers, despite being the only practitioners, are relegated to the receiving end of policy. Many teachers, particularly those who qualified prior to a post-apartheid context, would not have been immersed into initial teacher education programmes that speak to a recognition of religious diversity. Providing these teachers with content material on RE, as is currently the case, will not capacitate them to step out of who they are, and what they know. For the National Policy on Religion and Education (DoE 2003) to realise its potential, due cognisance has to be given not only to the narrative knowledge of teachers but also to how religious institutions and leaders might support the agenda of mutual regard and peaceful coexistence. Problems of intolerance, discrimination, and bigotry are not limited to schools; these represent broad-based societal dystopias. As such, what is needed is an investment in internalisation/indigenisation, i.e. 're-contextualisation', reflection and evaluation to discern whether the expectations of borrowing have been realistic or not before the results of that evaluation trigger the whole process of reflection once again.

\section{BIBLIOGRAPHY}

Aldridge, D. 2018. Religious education's double hermeneutic, British Journal of Religious Education, 40:3, 245-256, DOI: 10.1080/01416200.2018.1493267 
Exploring the Potential for Religious Scholarship in 'Post' Post-Confessional Religion Education 13

APPG on RE. 2013. RE: The truth unmasked. Accessed November 28,

2014. http://religiouseducationcouncil.org.uk/media/file/APPG_RE_-

_The_Truth_Unmasked.pdf

Bowie, R.A. and Coles, R. 2018. We reap what we sew: perpetuating biblical illiteracy in new English Religious Studies exams and the proof text binary question, British Journal of Religious Education, 40:3, 277287, DOI: 10.1080/01416200.2018.1493270

Briggs, R. 1986. When the Wind Blows. Penguin Books, London.

Bruner, J. 1996. "Folk pedagogies." In The culture of education, 44-65. Cambridge MA: Harvard University Press.

Carson, R., Wilson, E. O., Lear, L.J., Darling, L., and Darling, L. (2002). Silent spring. First Mariner books edition. Boston: Houghton Mifflin. Corrado, E. 2013. The godliness of apartheid planning the legitimizing role of the Dutch Reformed Church https://www.ideals.illinois.edu/handle/2142/45241 (accessed 13/03/2018).

Davids, N \& Orchard, J. (accepted for publication) 'Religious illiteracy and the dilemmas facing post-confessional RE in South African schools'. in: Motemba, Yonah, and Collett, Bruce (eds), The Bloomsbury handbook of Religious Education in the Global South. London: Bloomsbury Academic.

Davids, N. (2019) Democratic citizenship education in South Africa: Can we trust our teachers? In Pineda-Alfonso, J.A., De Alba-Fernández, N. and Navarro-Medina, E. (eds.), Handbook of research on education for participative citizenship and global prosperity. Pp. 45 - 66. Pennsylvania: IGI Global International publisher.

Department of Basic Education (DBE). 2011. Curriculum and Assessment Policy Statement (CAPS). Pretoria: Government Printers.

Department of Education (DoE). 2003. National policy on religion and education. Pretoria: Government Printers.

Docherty, S. 2018. A new dialogue between biblical scholarship and Religious Education, British Journal of Religious Education, 40:3, 298307, DOI: $10.1080 / 01416200.2018 .1493272$

Driesen, D. and Tayob, A. 2016. 'Negotiating religious literacy between National Policy and Catholic School ethos in Cape Town, South Africa'. In J. Berglund, J,, . Shanneik, Y., and Bocking, B. (eds.), Religious education in a global-local world. Dordrecht: Springer. 71-84.

Ehrlich, P.R. 1968. The population bomb. New York: Ballantine Books.

Ferreira, C. and Schulze, S. 2014. Teachers' experience of the implementation of values in education in schools: "Mind the gap", South African Journal of Education, 34(1):1-13.

Gore, A. 1992. Earth in the balance: Ecology and the human spirit. Boston MA: Houghton Mifflin.

Monbiot, G. 2020. Covid-19 is nature's wake-up call to complacent civilisation https://www.theguardian.com/commentisfree/2020/mar/25/covid-19-is-natureswake-up-call-to-complacent-civilisation (accessed $20^{\text {th }}$ June 2020).

Nogueira-Godsey, E. 2016. Recent observations on religion education in South Africa, British Journal of Religious Education, 38(3):229-235. 
Ntho-Ntho, A.M. \& Nieuwenhuis, J. 2016. Religion in education policy in South Africa: a challenge of change, British Journal of Religious Education, 38(3):236248.

Orchard, J, Heilbronn, R and Winstanley, C. 2020. In philosophical conversation with: New and beginning teachers pp145-162. In Fulford, A., Lockrobin, G., and Smith, R. (eds.), 'Philosophy and Community: Theories, Practices and Possibilities edited by Amanda Fulford, Grace Lockrobin and Richard Smith. Bloomsbury Academic, London.

Orchard, J. \& Davids, N. 2019. Philosophy for teachers (P4T) in South Africa - Reimagining provision to support new teachers' applied ethical decision-making, Ethics and Education, 14(3):333-350.

Orchard, J., Heilbronn, R., and Winstanley, C. 2016. Philosophy for teachers (P4T): Developing new teachers' applied ethical-decision making. Ethics and Education, 11(1), 42-54. https://doi.org/10.1080/17449642.2016.1145495

Orchard, J. (2015) Does religious education promote good community relations? Journal of Beliefs \& Values, 36:1, 40-

53, DOI: 10.1080/13617672.2015.1021125

Panjwani, F \& Revell, L. 2018. Religious education and hermeneutics: the case of teaching about Islam, British Journal of Religious Education, 40:3, 268-276,

Phillips, D. \& Ochs, K. 2004. Researching policy borrowing: Some methodological challenges in comparative education, British Educational Research Journal, Vol. 30, No. 6 pp. 773-784.

Ochs, K. \& Phillips, D. 2002. Comparative studies and 'cross-national attraction' in education: a typology for the analysis of English interest in educational policy and provision in Germany, Educational Studies, 28(4), 325-339

Phillips, D. 1993. Borrowing educational policy, in Finegold, D., McFarland, L., and Richardson, W. (eds.), Something borrowed, something learned? The transatlantic market in education and training reform. Washington, DC, The Brookings Institute. 13-19.

Phillips, D. 1989. Neither a borrower nor a lender be? The problems of cross-national attraction in education, Comparative Education, 25(3), 267-274.

REC 2013. A Review of religious education in England, The Religious Education Council of England and Wales

https://www.natre.org.uk/uploads/Free\%20Resources/2013\%20Review\%20of\%20Reli gious\%20Education\%20in\%20England.pdf

REC 2018. A new vision for religious education in schools, Commission on religious education https://www.commissiononre.org.uk/

Roux, C. 2010. Religion and human rights literacy as prerequisite for interreligious education. In Engebretson, K., de Sousa, M., Durka, G., and Gearon, L. (eds.), International handbook of inter-religious education, Part two. Dordrecht: Springer. 991-1015.

Staff reporter. (2017). NGO seeks declaring adherence to one religion at schools as unconstitutional. https://mg.co.za/article/2017-04-18-00-ngo-seeks-orderdeclaring-adherence-to-one-religion-as-unconstitutional/ 
Exploring the Potential for Religious Scholarship in 'Post' Post-Confessional Religion Education 15

Teece, G. 2008. Learning from religions as 'skilful means': A contribution to the debate about the identity of religious education, British Journal of Religious Education 30(3):187-198. DOI: 10.1080/01416200802170037

Wright, A. 1996. The child in relationship: towards a communal model of spirituality. In Best, R. (ed.), Education spirituality and the whole child (pp. 139-149). London: Cassell.

Wright, K. 2017. A pedagogy of embrace: a theology of hospitality as a pedagogical framework for religious education in Church of England schools. Doctoral thesis, University of East Anglia. 